\title{
Chemotherapeutic drugs in Lebanese surface waters: estimation of population exposure and identification of high-risk drugs
}

\author{
Yolande Saab ${ }^{1 *}$ (D) Zahi Nakad ${ }^{2}$ and Rita Rahme ${ }^{1}$
}

\begin{abstract}
Environmental risks imposed by anti-cancer drugs and their degradation products are a major concern worldwide. The consumption of anticancer drugs is increasing throughout the years and conventional water treatment processes seem to be ineffective for their removal. The aim of this study is to analyze the consumption of anticancer drugs in Lebanon and assess their potential health hazard as contaminants of the Lebanese surface waters. Anticancer drugs consumption data between the years 2013 and 2018 were collected and the following parameters were calculated: yearly consumption of single active ingredients, yearly consumption of drug equivalents (for drugs belonging to the same pharmacologic class having the same active ingredient) and Predicted Environmental Concentrations (PECs). The obtained PEC values were used to stratify compounds into risk categories. The top five most commonly consumed drugs are Mycophenolate mofetil, Hydroxycarbamide, Capecitibine, Mycophenolic acid and Azathioprine. Based on the calculated PEC values of single active ingredients as well as their equivalents, six high-risk priority compounds were identified: Mycophenolate mofetil, Hydroxycarbamide, Capecitibine, Mycophenolic acid, Azathioprine and 5-

Fluorouracil. The impact of these micropollutants on animals as well as humans was analyzed. This research stresses the importance of further analysis of chemotherapy micropollutants with major focus on high-risk drugs. Additionally, regulations should be set in place to ensure proper management of wastewater and the development of efficient wastewater treatment plants.
\end{abstract}

Keywords: Anticancer drugs, Toxicity, Risk assessment, Surface waters, Lebanon

\section{Introduction}

Cancer is the second leading cause of death in the world. Every sixth death in the world is due to cancer [1]. In Lebanon, the number of new cancer cases diagnosed in 2018 were 17,294 (288 cases per 100,000 population) with breast, bladder, lung, prostate, and colorectal cancers being the most common [2]. As the world population is growing and aging, the global number of cancer death is expected to increase further. Chemotherapy is

\footnotetext{
* Correspondence: ysaab@lau.edu.lb

${ }^{1}$ Department of Pharmaceutical Sciences, School of Pharmacy, Lebanese American University, Byblos 36-F19, Lebanon

Full list of author information is available at the end of the article
}

often used as a major treatment for almost all types of cancer. Cytotoxic drugs are a group of compounds used in chemotherapy to prevent or disrupt cell division. Many of these drugs are mutagenic, carcinogenic, teratogenic and/or toxic to reproductive systems and are classified as highly hazardous compounds [3].

Anticancer drugs present a major water contaminant worldwide; Lebanon's case is not less worrisome. Environmental risk assessment of anti-cancer drugs and their transformation products is a major concern; studies have been conducted to analyze chemotherapy drugs consumption trends, presence in surface water and population exposure. This is due to two main factors: the consumption

(c) The Author(s). 2021 Open Access This article is licensed under a Creative Commons Attribution 4.0 International License, which permits use, sharing, adaptation, distribution and reproduction in any medium or format, as long as you give

appropriate credit to the original author(s) and the source, provide a link to the Creative Commons licence, and indicate if changes were made. The images or other third party material in this article are included in the article's Creative Commons licence, unless indicated otherwise in a credit line to the material. If material is not included in the article's Creative Commons licence and your intended use is not permitted by statutory regulation or exceeds the permitted use, you will need to obtain permission directly from the copyright holder. To view a copy of this licence, visit http://creativecommons.org/licenses/by/4.0/. 
of chemotherapeutic agents is increasing throughout the years and conventional water treatment processes seem to be ineffective for removal of anti-cancer drugs and their transformation products. Many research studies reported that wastewater treatment plants (WWTPs) even those that meet regulatory requirements for wastewater treatment are only moderately effective in removing the aforementioned pharmaceuticals [4-7]. The pharmacologic and mutagenic properties of chemotherapy drugs potentially make anticancer drugs the most dangerous contaminant of our water system and pose a risk to the aquatic life and human beings. Available ecotoxicological data for anti-cancer drugs and their metabolites are incomplete. So far, the situation in Lebanon was not evaluated by any environmental risk assessment studies. Our work is the first to present an overview of the consumption trends in Lebanon, to forecast the presence of the associated contaminants in surface waters, and to conclude with an assessment of the correlated risks. The assessment will take into consideration the pharmacokinetic properties (metabolism and excretion) of each of the anticancer drugs analyzed.

The aim of the study is to investigate the consumption of anticancer drugs and assess their potential health hazard as contaminants in the Lebanese surface waters.

\section{Materials and methods}

The work is divided into four steps:

- Study the consumption of chemotherapy drugs in Lebanon over the years 2013 to 2018.

- Compute the concentration of these drugs in surface water.
- Investigate the exposure of the Lebanese population to anticancer drugs.

- Assess the long-term risks associated with this exposure and the potential effect in Lebanon as well as countries on the Mediterranean Sea.

\section{Anticancer drugs' consumption}

The brand names of cancer drugs available on the Lebanese market and registered at the Ministry of Public Health $(\mathrm{MOPH})$ were identified, and the yearly consumption of each drug consumed between 2013 and 2018 was studied. Data comprised all the dosage forms available on the Lebanese market including tablets, capsules and injectable drugs. As per the $\mathrm{MOPH}$, anticancer drugs are classified as: endocrine therapy, immunosuppressive agents and antineoplastic agents.

\section{Data collection and concentration in surface water}

Consumption data was identified for 259 anti-neoplastic drugs over 6 years. The total amount of active ingredients consumed over the years was calculated based on the following:

- For every brand drug, consumption per year (in mg) was calculated using the number of boxes (preparations) consumed times the number of units/box and the amount of active ingredients in each unit (in $\mathrm{mg}$ ).

- Drugs with the same active ingredient were grouped together and their consumption was summed up.

- When applicable, different active ingredients belonging to the same pharmacologic or chemical class were grouped together. Total consumption in every drug class was calculated using conversion factors, as provided in Table 1.

Table 1 Active ingredients in each class of anticancer drugs and the factors used in the conversion

\begin{tabular}{|c|c|c|}
\hline Drug class & Active ingredients & Conversion factor \\
\hline Inosine monophosphate dehydrogenase inhibitor & $\begin{array}{l}\text { - Mycophenolic acid (MPA) } \\
\text { - Mycophenolate mofetil (MMF) }\end{array}$ & $1440 \mathrm{mg}$ MPA = 2000 mg MMF [8] \\
\hline Antimetabolites & $\begin{array}{l}\text { - Capecitabine } \\
\text { - 5-Fluorouracil }\end{array}$ & 2.76 mg CAP = 1 mg 5-Fluorouracil [9] \\
\hline Alkylating agents & $\begin{array}{l}\text { - Cyclophosphamide } \\
\text { - Ifosfamide }\end{array}$ & 1 mg cyclophosphamide $=0.244$ ifosfamide [10] \\
\hline Anthracyclins & $\begin{array}{l}\text { - Epirubicin } \mathrm{HCl} \\
\text { - Mitoxantrone } \\
\text { - Doxorubicin } \\
\text { - Idarubicin HCl }\end{array}$ & $\begin{array}{l}75 \mathrm{mg} \text { Epirubicin }=12.50 \mathrm{mg} \text { Mitoxantrone }=50 \mathrm{mg} \\
\text { Doxorubicin }=10 \mathrm{mg} \text { idarubicin [11] }\end{array}$ \\
\hline Taxanes & $\begin{array}{l}\text { - Docetaxel } \\
\text { - Paclitaxel }\end{array}$ & 135 mg Paclitaxel = 75 mg Docetaxel \\
\hline Antimetabolites & $\begin{array}{l}\text { - Methotrexate } \\
\text { - Pemetrexed }\end{array}$ & 1.50 mg Methotrexate = 150 mg Pemetrexed [12] \\
\hline LHRH agonist: Goserelin equivalent & $\begin{array}{l}\text { - Goserelin } \\
\text { - Leuprorelin } \\
\text { - Triptorelin }\end{array}$ & $\begin{array}{l}3.60 \mathrm{mg} \text { Goserelin }=7.50 \mathrm{mg} \text { Leuprorelin }=3.75 \mathrm{mg} \\
\text { Triptorelin [13] }\end{array}$ \\
\hline
\end{tabular}


- Cumulative concentration was calculated by summing the total consumption per year for the years 2013 to 2018 .

\section{Exposure based classification}

Pharmaceuticals that are used in higher amounts have a potential to reach the aquatic environment in greater quantities and therefore present a higher risk to human and aquatic life. Consequently, risk classification is done according to quantity consumed. The classification of compounds based on exposure is done using Predicted Environmental Concentrations (PECs), according to Scheme 1. Thresholds for risk classification adopted in the analysis are $100 \mathrm{ng} \mathrm{L}^{-1}$ (guidance by the Food and Drug Administration [15] and $10 \mathrm{ng} \mathrm{L}^{-1}$ (guidance by European Medicine Agency (EMA)) [16]. Two PEC values were determined:

- $\mathrm{PEC}_{\mathrm{a}}$ assumes no metabolism of the active ingredient happens in the body, 100\% of the active ingredient is excreted unchanged (worst case scenario).

$$
\mathrm{PEC}_{\mathrm{a}}=\frac{\text { consumption }}{\text { WWinhab } \times \text { inhab } \times D F}
$$

where consumption is the amount of active ingredient consumed per year $\left(\mathrm{ng} \mathrm{yr}^{-1}\right)$, WWinhab is the water consumption per person per year, Inhab is the number of inhabitants of Lebanon and DF is the dilution factor from WWTPs effluents to surface water.
- $\mathrm{PEC}_{\mathrm{b}}$ is calculated when metabolism data is available for the drug. The fraction of active ingredient excreted unchanged (Fexc) is added to the equation.

$\mathrm{PEC}_{\mathrm{b}}=\frac{\text { consumption }}{\text { WWinhab } \times \text { inhab } \times D F} x$ Fexc

- $\mathrm{PEC}_{\mathrm{c}}$ is the predicted concentration in surface water that remains after treatment. Therefore, $\mathrm{PEC}_{\mathrm{c}}$ is obtained by taking into consideration the fraction of pharmaceuticals removed by WWTPs (FWWTP). However, due to the absence of efficient treatment plants in Lebanon, $\mathrm{PEC}_{\mathrm{c}}$ and $\mathrm{PEC}_{\mathrm{b}}$ values are assumed to be equal.

$$
\mathrm{PEC}_{\mathrm{c}}=\frac{\text { consumption }}{\text { WWinhab } \times \text { inhab } \times D F} x \text { Fexc } x\left(1-F_{W W T P}\right)
$$

The following assumptions were made when using the formula:

- According to the EMA guidelines, the amount of wastewater per inhabitant per day can be assumed to be equal to $200 \mathrm{~L}$. The yearly consumption (WWinhab) would therefore be equal to 73,000 L inhab ${ }^{-1} \mathrm{yr}^{-1}$ [16].

- The number of inhabitants in Lebanon was assumed to be equal to $6,000,000$ [17].

- The Dilution Factor was assumed to be equal to 10 as per the EMA guidelines.

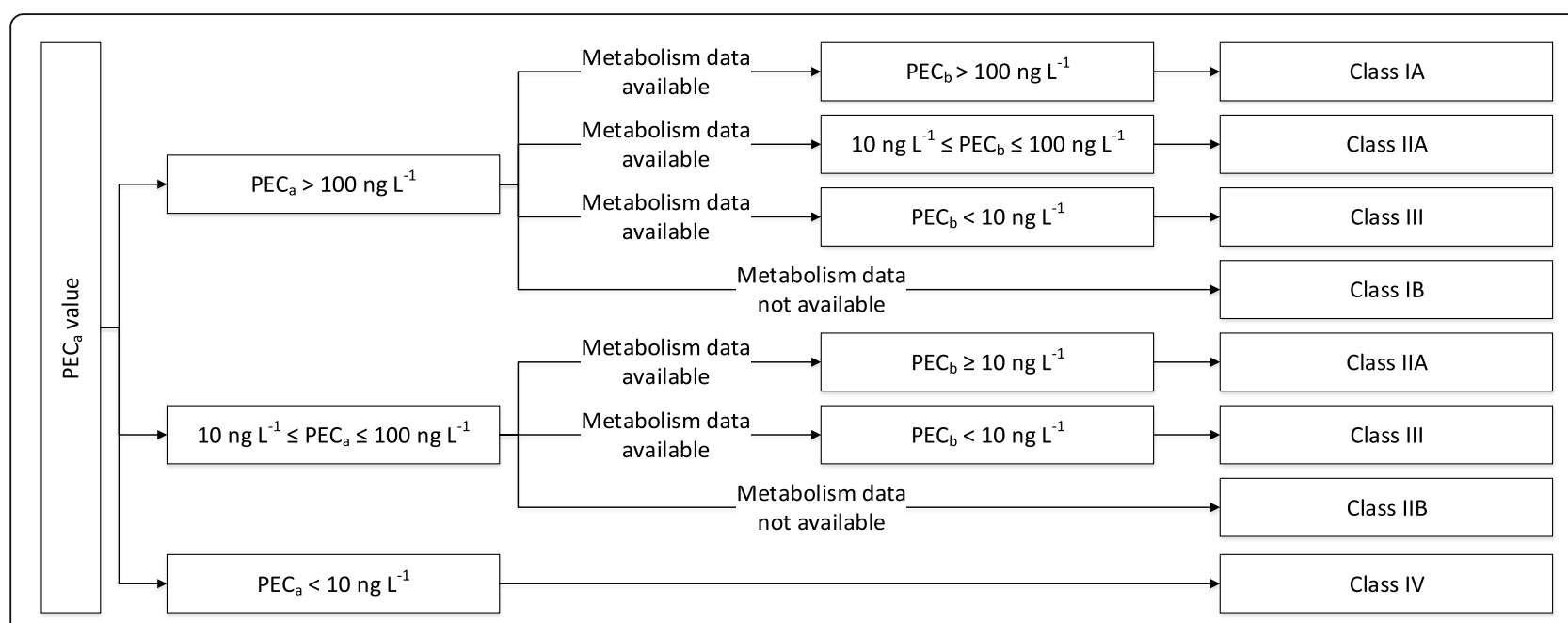

Scheme 1 Classification of compounds based on potential $P E C_{a}$ and $P E C_{b}$ values, adapted from Santos et al. [14] 
- The fraction of active ingredient excreted unchanged was assumed to be equal to 0.5 when data was not available.

\section{Toxicity classification}

Depending on $\mathrm{PEC}_{\mathrm{a}}$ and $\mathrm{PEC}_{\mathrm{b}}$ values obtained for each drug, a different class was assigned to each drug. Drugs were categorized into six classes from the highest to the lowest risk, as explained in Table 2.

\section{Results}

\section{Anticancer drugs consumption in Lebanon}

The top five drugs with the highest total consumption (2013-2018) are (in decreasing order): Mycophenolate mofetil (MMF), Hydroxycarbamide, Capecitibine, Mycophenolic acid (MPA) and Azathioprine (Fig. 1).

The most consumed drug, MMF is a reversible inhibitor of inosine monophosphate dehydrogenase. MMF is an ester prodrug of MPA and should be considered as a source of MPA in terms of environmental contamination [18]. Accordingly, consumption data of both drugs were grouped together based on the conversion factor presented in Table 1 . The yearly consumption of both drugs and their equivalent total MPA is presented in Fig. 2. The second most commonly consumed drug is Hydroxycarbamide, also known as hydroxyurea [18]. It exhibits its antineoplastic effect through inhibition of DNA synthesis. The third most commonly consumed drug is capecitabine. Capecitabine is a prodrug that is enzymatically converted to fluorouracil (antimetabolite) in the tumor, where it inhibits DNA synthesis and slows growth of tumor tissue $[9,18]$. The environmental toxicity of capecitabine should therefore be analyzed as part of that of Fluorouracil. The yearly consumption of both drugs and their equivalent 5-Fluorouracil is presented in Fig. 3. The fourth most commonly consumed drug is MPA and the fifth is azathioprine, a purine analogue with cytotoxic and immunosuppressive activity [18]. Figure 4 illustrates the change in the consumption of each of the commonly consumed chemotherapeutic drugs over the years 2013-2018.

Table 2 Classification of compounds based on potential exposure $\left(\mathrm{PEC}_{\mathrm{a}}\right.$ and $\mathrm{PEC}_{\mathrm{b}}$ values): risk categories

\begin{tabular}{ll}
\hline Class & Risk \\
\hline Class IA & High-risk compounds \\
Class IB & Potentially hazardous compounds but limited data \\
Class IIA & Potentially hazardous compounds \\
Class IIB & Unclassified risk \\
Class III & Very low risk \\
Class IV & Very low risk \\
\hline
\end{tabular}

\section{Exposure-based classification}

In this section, in order to better reflect on exposure, anticancer drugs pharmacokinetic parameters are considered (metabolism and excretion) by calculating PEC values. Details on the $\mathrm{PEC}_{\mathrm{a}}$ and $\mathrm{PEC}_{\mathrm{b}}$ results along with the classification of the drugs are presented in a separate document. As we can see in Table 3, most of the drugs belong to Class IV and III, both indicative of a very low risk of environmental toxicity. High-risk compounds (class IA) include MMF and MMF equivalent. Potentially hazardous compounds, belonging to Class II, include azathioprine, capecitabine, Hydroxycarbamide, MPA, and 5-fluorouracil equivalent. Therefore, from the 259 anti-neoplastic agents available on the Lebanese market, the previously enumerated 6 compounds should be considered as priority for further evaluation. Table 4 shows $\mathrm{PEC}_{\mathrm{a}}$ and $\mathrm{PEC}_{\mathrm{b}}$ values as well as the risk categorization of the priority anticancer drugs and their respective equivalents. Figure 5 presents the $\mathrm{PEC}_{\mathrm{b}}$ value for the priority anticancer drugs.

\section{Discussion \\ Analysis of the results}

MMF is the most commonly consumed drug. The main reason behind the elevated consumption of MMF prodrug and its active ingredient MPA is that they are used as both chemotherapeutic and immunosuppressive agents (in organ transplantation and auto-immune disease) [19]. The PEC values calculated for the MPA equivalent led to risk categorization of the MPA equivalent into either class IIA or class IA for different years, indicating that MPA is a potentially hazardous compound. In contrast, when MPA was analyzed as a separate entity of MMF, it was classified into class IIA and class III for different years underestimating its potential toxicity. The consumption trend of MMF and MPA was consistent between the years 2013 and 2018. In comparison with global consumption, MMF consumption in Lebanon is $329 \mu \mathrm{g}$ Inhabitant ${ }^{-1} \mathrm{~d}^{-1}$, lower than its consumption in Portugal (593 $\mu$ g Inhabitant $\left.{ }^{-1} \mathrm{~d}^{-1}\right)$ [14]. As for MPA, its consumption in Lebanon equals $72 \mu \mathrm{g}$ Inhabitant $^{-1} \mathrm{~d}^{-1}$, higher than in Portugal $(50 \mu \mathrm{g}$ Inhabitant $\left.{ }^{-1} \mathrm{~d}^{-1}\right)$ ) [14] and Poland (51 $\mu \mathrm{g}_{\text {Inhabitant }}^{-1}$ $\left.\mathrm{d}^{-1}\right)$ [19] but lower than in Catalonia $(704 \mu \mathrm{g}$ Inhabitant $^{-1} \mathrm{~d}^{-1}$ ) [20].

The second most commonly consumed drug is hydroxycarbamide. This could be explained by the fact that hydroxycarbamide is highly consumed in the Middle East and Africa region and it is relatively cheaper than other chemotherapeutic drugs [21]. Its consumption approximately doubled between the years 2013 and 2018. It was classified, according to the calculated PEC values, in class IIA (potentially hazardous compounds) for the years 2013-2018. In comparison with global 


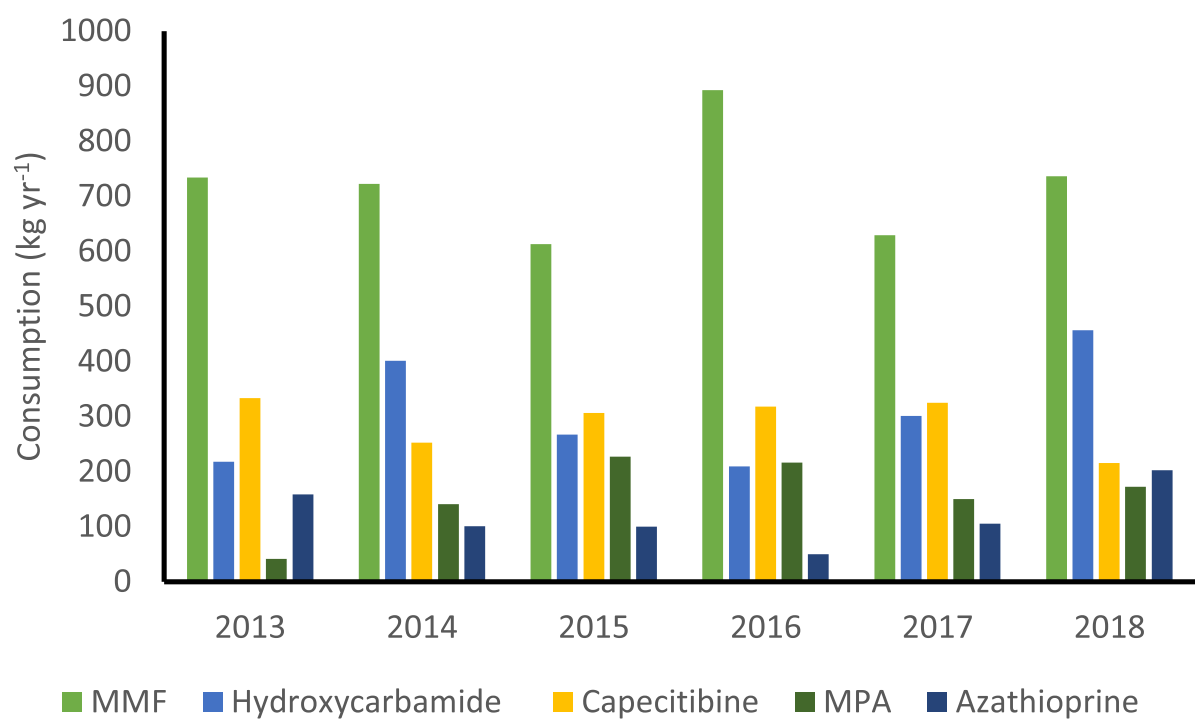

Fig. 1 Top 5 most commonly consumed anticancer drugs in Lebanon between 2013 and 2018

consumption, the consumption of hydroxycarbamide in Lebanon is equal to $141 \mu \mathrm{g}$ Inhabitant ${ }^{-1} \mathrm{~d}^{-1}$, higher than in the UK $\left(33 \mu \mathrm{g}\right.$ Inhabitant $\left.{ }^{-1} \mathrm{~d}^{-1}\right)$ [22] but lower than in Portugal $\left(253 \mu \mathrm{g}\right.$ Inhabitant $\left.{ }^{-1} \mathrm{~d}^{-1}\right)$ [14], Catalonia $\left(221 \mu \mathrm{g}\right.$ Inhabitant $\left.^{-1} \mathrm{~d}^{-1}\right)$ [20] and France $(284 \mu \mathrm{g}$ Inhabitant ${ }^{-1} \mathrm{~d}^{-1}$ ) [23].

The third most commonly consumed drug is Capecitibine. Capecitabine is a widely used chemotherapeutic drug as it has gained approval in two of the most common cancers in Lebanon: breast and colorectal cancer [2]. Additionally, a global trend towards the prescribing of capecitabine over fluorouracil as capecitabine allows more patient-friendly oral administration, improved quality of life and fewer side effects [24]. It is worth noting that consumption data of fluorouracil for the years 2014 to 2016 was absent from the provided data. Accordingly, the extent/trend in its consumption was not clear. As previously mentioned in the results section, capecitabine is a prodrug of 5-fluorouracil. Accordingly, the consumption of both was grouped using drugspecific equivalence factors under a total 5-fluorouracil equivalent. The PEC values calculated for the equivalent lead to its risk categorization into class IIA for the years 2013-2018, indicating that 5-fluorouracil is a potentially hazardous compound. This again proves that a separate analysis of capecitabine and 5-fluorouracil will lead to an underestimation of the toxicity of each of the drugs, as 5-fluorouracil analyzed separately was classified into

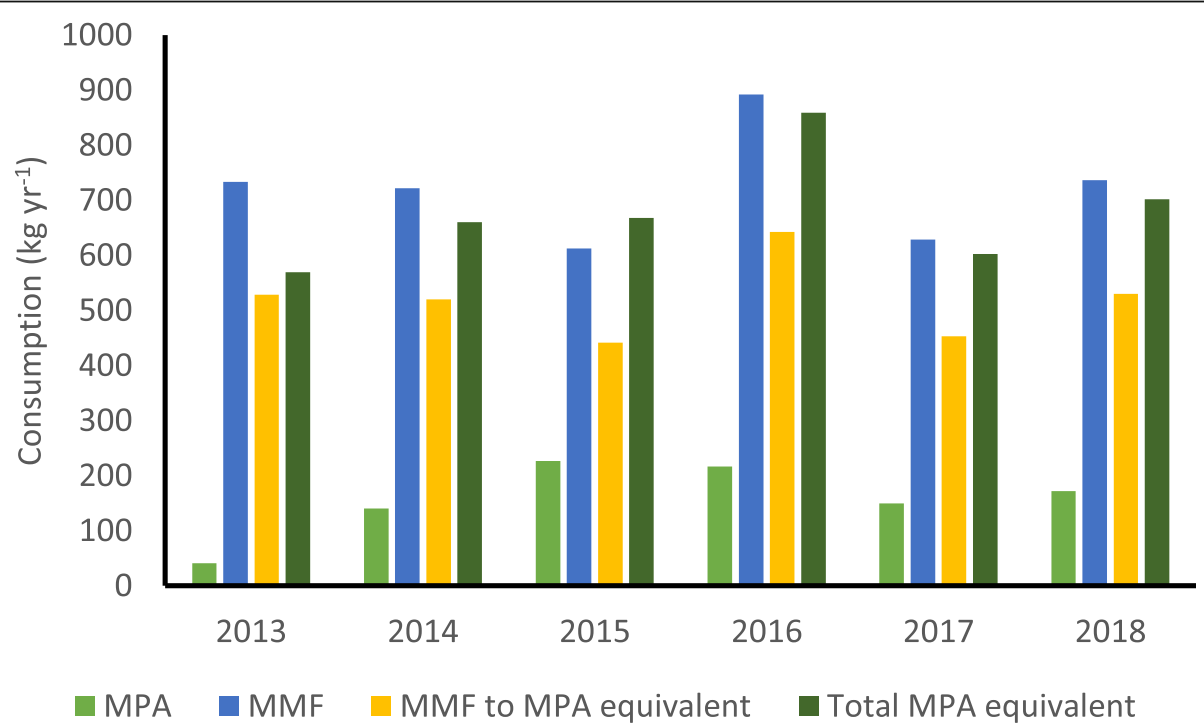

Fig. 2 Yearly consumption of MMF, MPA and their equivalent MPA between 2013 and 2018 


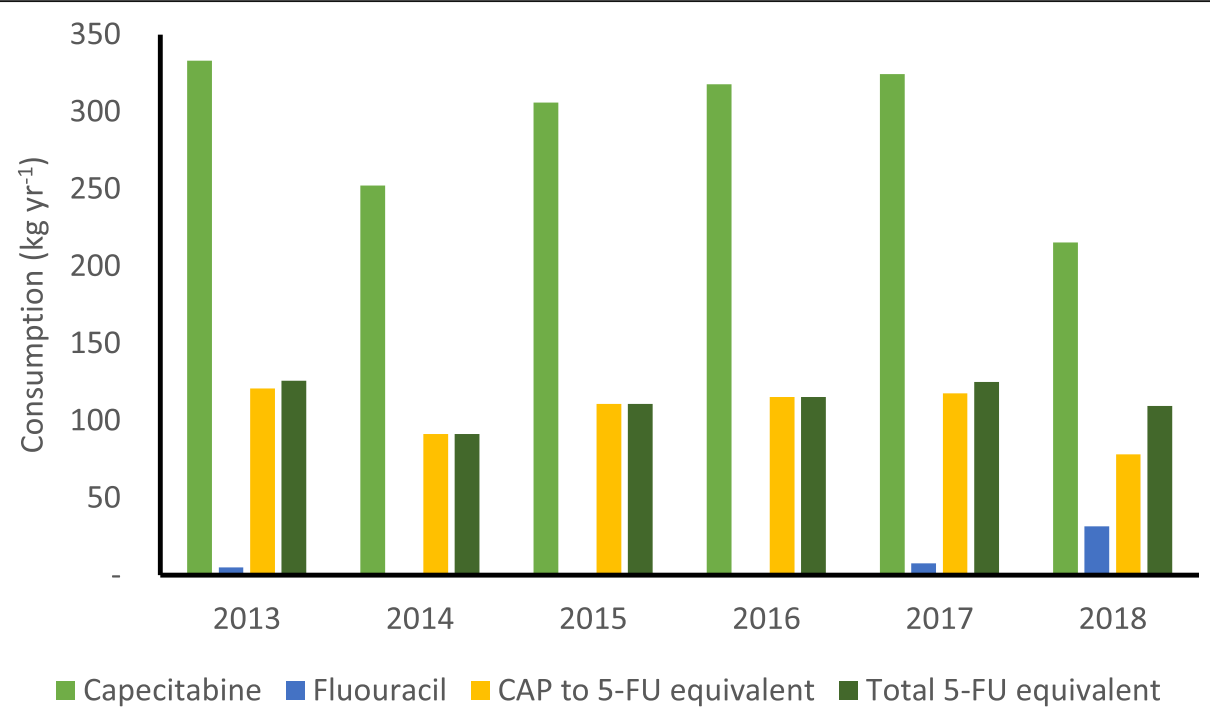

Fig. 3 Yearly consumption of capecitabine, 5-fluorouracil, and their equivalent (2013-2018)

class IV (very low risk). The consumption of capecitabine decreased by one-third between the years 2013 and 2018. In comparison with global consumption, the consumption of capecitabine in Lebanon is equal to $133 \mu \mathrm{g}$ Inhabitant ${ }^{-1} \mathrm{~d}^{-1}$, lower than that in Portugal $(206 \mu \mathrm{g}$ go Inhabitant $\left.^{-1} \mathrm{~d}^{-1}\right)$ [14], Catalonia $\left(28 \mu \mathrm{g}\right.$ Inhabitant $^{-1}$ $\left.\mathrm{d}^{-1}\right)$ [20], France $\left(213 \mu \mathrm{g}\right.$ Inhabitant $\left.{ }^{-1} \mathrm{~d}^{-1}\right)$ [23], and UK $\left(183 \mu \mathrm{g}\right.$ Inhabitant $\left.{ }^{-1} \mathrm{~d}^{-1}\right)$ [22]. As for 5-fluorouracil, its consumption in Lebanon is equal to $6.7 \mu \mathrm{g}$ Inhabitant $^{-1}$ $\mathrm{d}^{-1}$ and it is higher than that in Catalonia $(0.70 \mu \mathrm{g}$ Inhabitant ${ }^{-1} \mathrm{~d}^{-1}$ ) [20] and lower than those in Portugal $\left(63 \mu \mathrm{g}\right.$ Inhabitant $\left.^{-1} \mathrm{~d}^{-1}\right)$ [14], France $\left(71 \mu \mathrm{g}\right.$ Inhabitant $^{-1}$ $\left.\mathrm{d}^{-1}\right)$ [23] and UK (46 $\mu \mathrm{g}$ Inhabitant $\left.{ }^{-1} \mathrm{~d}^{-1}\right)$ [22].

The fifth most commonly consumed drug is Azathioprine. Azathioprine is a cytotoxic and an immunosuppressant drug indicated in kidney transplantation and rheumatoid arthritis. Its high consumption can be explained by the wide prevalence of rheumatoid arthritis disease in the Lebanese population versus the global population, $1 \%$ and 0.5 to $1 \%$, respectively [25]. Azathioprine use has remained the same between years 2013 and 2018; it was classified according to the calculated

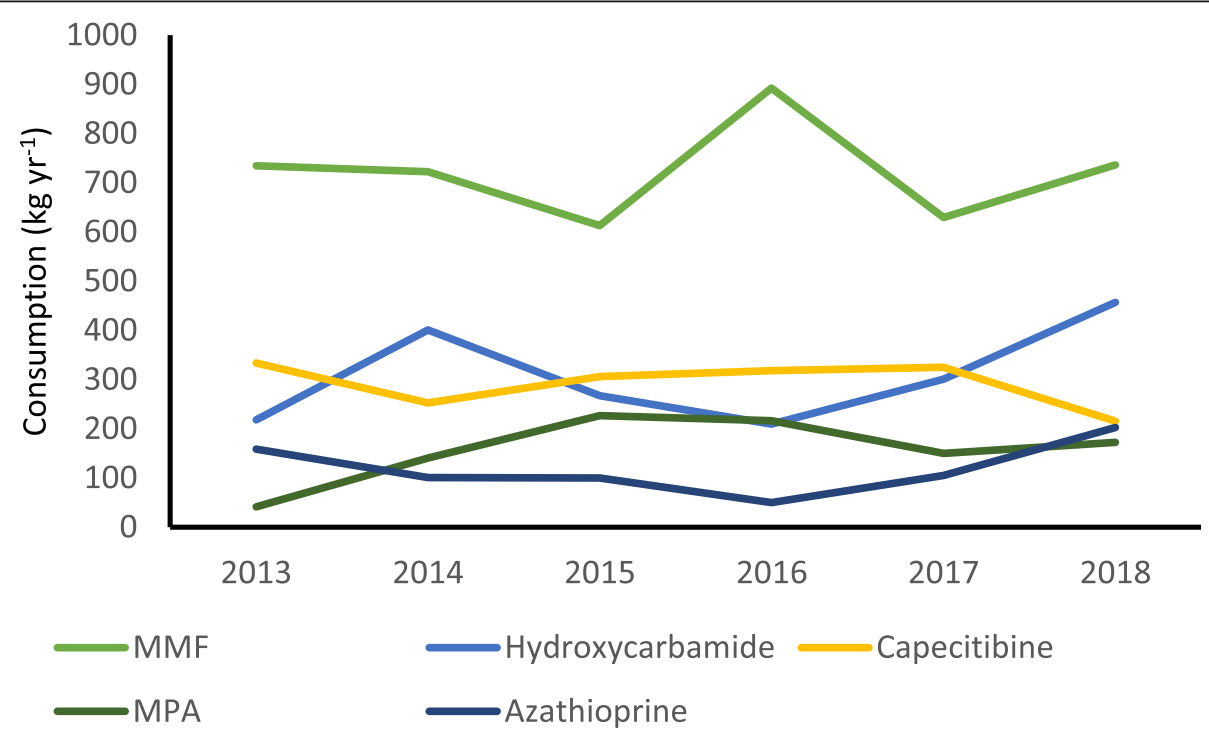

Fig. 4 Trend in the consumption of commonly prescribed chemotherapeutic drugs (2013-2018) 
Table 3 Risk categorization of chemotherapeutic drugs based on environmental exposure data between 2013 and 2018

\begin{tabular}{|c|c|c|c|c|c|}
\hline CLASS IA & Class IIA & Class III & CLASS IV & & \\
\hline $\begin{array}{l}\text { Mycophenolate mofetil (2013- } \\
\text { 2014, 2016) Mycophenolic acid } \\
\text { equivalent (2016) }\end{array}$ & $\begin{array}{l}\text { Azathioprine (2013-2015, 2017-2018) } \\
\text { Capecitibine Hydroxycarbamide } \\
\text { Mycophenolate mofetil }(2015,2017,2018) \\
\text { Mycophenolic acid }(2014-2018) \\
\text { Mycophenolic acid equivalent }(2013-2015, \\
\text { 2017-2018) } \\
\text { 5-fluorouracil equivalent }\end{array}$ & $\begin{array}{l}\text { Mycophenolic } \\
\text { acid (2013) } \\
\text { Tamoxifen } \\
\text { (2015-2018) } \\
\text { Imatinib } \\
\text { (2013-2016) } \\
\text { Azathioprine } \\
\text { (2016) } \\
\text { Ciclosporin } \\
\text { (2014) }\end{array}$ & $\begin{array}{l}\text { Imatinib (2017- } \\
\text { 2018) } \\
\text { Afatinib } \\
\text { Imatinib } \\
\text { Alectinib } \\
\text { Anastrazole } \\
\text { Apremilast } \\
\text { Axitinib } \\
\text { Azacitidine } \\
\text { Baricitinib } \\
\text { Bendamustine HCl } \\
\text { Bicalutamide } \\
\text { Bleomycin } \\
\text { Busulfan } \\
\text { Cabazitaxel } \\
\text { Carboplatin } \\
\text { Carfilzomib } \\
\text { Ciclosporin } \\
\text { (2013,2015-2018) } \\
\text { Cisplatin } \\
\text { Clofarabine } \\
\text { Cladribine } \\
\text { Crizotinib } \\
\text { Cyclophosphamide } \\
\text { Cytarabine } \\
\text { Dacarbazine } \\
\text { Dasatinib } \\
\text { Decitabine } \\
\text { Degarelix } \\
\text { Docetaxel } \\
\text { Doxorubicin } \\
\text { Enzalutamide }\end{array}$ & $\begin{array}{l}\text { Epirubicin } \mathrm{HCl} \\
\text { Eribulin } \\
\text { mesylate } \\
\text { Erlotinib } \\
\text { Etoposide } \\
\text { Everolimus } \\
\text { Exemestane } \\
\text { Fingolimod } \\
\text { Fludarabine } \\
\text { Fluorouracil } \\
\text { Fulvestrant } \\
\text { Gefitinib } \\
\text { Goserelin } \\
\text { Ibrutinib } \\
\text { Idarubicin } \mathrm{HCl} \\
\text { Ifosfamide } \\
\text { Irinotecan } \mathrm{HCl} \\
\text { Lapatinib } \\
\text { ditosylat } \\
\text { Leflunomide } \\
\text { Lenalidomide } \\
\text { Lenvatinib } \\
\text { Letrozole } \\
\text { Leuprorelin } \\
\text { Mercaptopurine } \\
\text { Mitoxantrone } \\
\text { Nilotinib } \\
\text { Nintedanib } \\
\text { Osimertinib } \\
\text { Paclitaxel } \\
\text { Palbociclib } \\
\text { Pazopanib HCl } \\
\text { Pemetrexed } \\
\text { Plerixafor } \\
\text { Methotrexate } \\
\text { equivalent }\end{array}$ & $\begin{array}{l}\text { Pomalidomide } \\
\text { Pralatrexate } \\
\text { Regorafenib } \\
\text { Ribociclib } \\
\text { Ruxolitinib } \\
\text { Sirolimus } \\
\text { Sorafenib } \\
\text { Sunitinib } \\
\text { maleate } \\
\text { Tacrolimus } \\
\text { monohydrate } \\
\text { Temozolomide } \\
\text { Teriflunomide } \\
\text { Thalidomide } \\
\text { Tofacitinib } \\
\text { Trabectedin } \\
\text { Trifluridine } \\
\text { Triptorelin } \\
\text { Vemurafenib } \\
\text { Venetoclax } \\
\text { Vincristine } \\
\text { sulfate } \\
\text { Vinflumine } \\
\text { Vinorelbine } \\
\text { Vismodegib } \\
\text { Oxaliplatin } \\
\text { Gemcitabine } \\
\text { Methotrexate } \\
\text { Tamoxifen } \\
\text { (2013-2014) } \\
\text { Methotrexate } \\
\text { equivalent } \\
\text { Docetaxel } \\
\text { equivalent } \\
\text { Doxorubicin } \\
\text { equivalent } \\
\text { Goserelin } \\
\text { equivalent }\end{array}$ \\
\hline
\end{tabular}

PEC values in class IIA (potentially hazardous compounds) for the years 2013-2018.

\section{Actual risk}

In this study, we have analyzed the risk imposed by chemotherapeutic micro-pollutants based on their yearly consumption. However, in fact, some chemotherapeutic drugs accumulate and their amounts in the environment build up over the years, alluding to a higher ecotoxicological risk. A review of the environmental fate of the top 5 most consumed drugs reveals that none of them is a potential bio-accumulative drug $[9,24,26]$. However, less commonly consumed chemotherapy drugs that can accumulate and potentially pose a serious environmental risk include Cyclophosphamide, Ifosfamide [27] and Erlotinib [28].

Another factor that should be taken into consideration is that the residues of pharmaceuticals occur in the environment as complex mixtures; even though the concentrations of an individual compound might be low, the cocktail effect might have a more concerning ecotoxicological implication. Research studies on the environmental concern of combinations of anticancer drugs revealed that the interactions of anticancer drugs could be of environmental concern [29-31].

\section{Impact on animals/humans}

Studies investigating the toxicity of chemotherapy drugs on animals are scarce and are usually done using higher concentrations than those found in the environment. Accordingly, additional work is needed to evaluate the acute and chronic risks associated with exposure to environmental concentrations. MPA risk evaluation studies have revealed that it can cause growth inhibition in green algae. The germination as well as root growth of certain seeds was significantly inhibited by MPA in a concentration-dependent manner. Additionally, the exposure of the cyano-bacterium Anabaena flos-aquae to MPA resulted in a clear concentration-response relationship on the growth rate of the bacteria [32]. A study by Kovacs et al. evaluated the chronic exposure of 5Fluorouracil to zebrafish at environmentally relevant concentrations. The results revealed that such exposure causes hepatic and renal histopathological changes, 
Table $4 \mathrm{PEC}_{\mathrm{a}}\left(\mathrm{ng} \mathrm{L}^{-1}\right), \mathrm{PEC}_{\mathrm{b}}\left(\mathrm{ng} \mathrm{L}^{-1}\right)$, and risk categorization of the priority anticancer drug and their corresponding equivalents between the years 2013 and 2018

\begin{tabular}{|c|c|c|c|c|c|c|c|}
\hline Active ingredient & Factor & 2013 & 2014 & 2015 & 2016 & 2017 & 2018 \\
\hline \multirow[t]{3}{*}{ Azathioprine } & $\mathrm{PEC}_{\mathrm{a}}$ & 46.9 & 29.6 & 27.3 & 13.0 & 26.9 & 51.1 \\
\hline & $\mathrm{PEC}_{\mathrm{b}}$ & 23.4 & 14.8 & 13.6 & 6.5 & 13.4 & 25.5 \\
\hline & Class & $\| \mathrm{A}$ & $\| \mathrm{A}$ & $\| \mathrm{A}$ & III & $\| A$ & $\| A$ \\
\hline \multirow[t]{3}{*}{ Capecitibine } & $\mathrm{PEC}_{\mathrm{a}}$ & 98.9 & 74.1 & 83.7 & 83.1 & 83.1 & 54.3 \\
\hline & $\mathrm{PEC}_{\mathrm{b}}$ & 49.9 & 37.0 & 41.8 & 41.5 & 41.5 & 27.1 \\
\hline & Class & $\| \mathrm{A}$ & $\| A$ & $\| A$ & $\| A$ & $\| A$ & $\| A$ \\
\hline \multirow[t]{3}{*}{ 5- fluorocuracil } & $\mathrm{PEC}_{\mathrm{a}}$ & 1.4 & NA & NA & NA & 1.9 & 7.9 \\
\hline & $P E C_{b}$ & 0.7 & NA & NA & NA & 0.9 & 3.9 \\
\hline & Class & IV & NA & NA & NA & IV & IV \\
\hline \multirow[t]{3}{*}{ Mycophenolic acid } & $\mathrm{PEC}_{\mathrm{a}}$ & 12.1 & 41.3 & 62.0 & 56.6 & 38.4 & 43.4 \\
\hline & $\mathrm{PEC}_{\mathrm{b}}$ & 6.1 & 20.6 & 31.0 & 28.3 & 19.2 & 21.7 \\
\hline & Class & III & $\| \mathrm{A}$ & $\| A$ & $\| A$ & $\| \mathrm{A}$ & $\| \mathrm{A}$ \\
\hline \multirow[t]{3}{*}{ Mycophenolate mofetil } & $\mathrm{PEC}_{\mathrm{a}}$ & 218.0 & 212.4 & 167.7 & 233.4 & 161.2 & 185.9 \\
\hline & $\mathrm{PEC}_{\mathrm{b}}$ & 109.0 & 106.2 & 83.8 & 116.7 & 80.6 & 92.9 \\
\hline & Class & $\mathrm{IA}$ & $\mathrm{IA}$ & $\| A$ & $\mathrm{IA}$ & $\| A$ & $\| A$ \\
\hline \multirow[t]{3}{*}{ Hydroxycarbamide } & $\mathrm{PEC}_{\mathrm{a}}$ & 64.7 & 117.9 & 73.1 & 54.8 & 77.1 & 115.2 \\
\hline & $\mathrm{PEC}_{\mathrm{b}}$ & 32.3 & 58.9 & 36.5 & 27.4 & 38.5 & 57.6 \\
\hline & Class & $\| A$ & $\| A$ & $\| A$ & $\| A$ & $\| A$ & $\| A$ \\
\hline \multirow[t]{3}{*}{ Mycophenolic acid equivalent } & $\mathrm{PEC}_{\mathrm{a}}$ & 169.1 & 194.2 & 182.8 & 224.7 & 154.4 & 177.2 \\
\hline & $\mathrm{PEC}_{\mathrm{b}}$ & 84.5 & 97.1 & 91.4 & 112.3 & 77.2 & 88.6 \\
\hline & Class & $\| A$ & $\| A$ & $\| A$ & $\mathrm{IA}$ & $\| A$ & $\| A$ \\
\hline \multirow[t]{3}{*}{ 5-fluorouracil equivalent } & $\mathrm{PEC}_{\mathrm{a}}$ & 37.3 & 26.8 & 30.3 & 30.1 & 32.0 & 27.6 \\
\hline & $P E C_{b}$ & 18.6 & 13.4 & 15.1 & 15.0 & 16.0 & 13.8 \\
\hline & Class & $\| \mathrm{A}$ & $\| A$ & $\| A$ & $\| A$ & $\| A$ & $\| \mathrm{A}$ \\
\hline
\end{tabular}

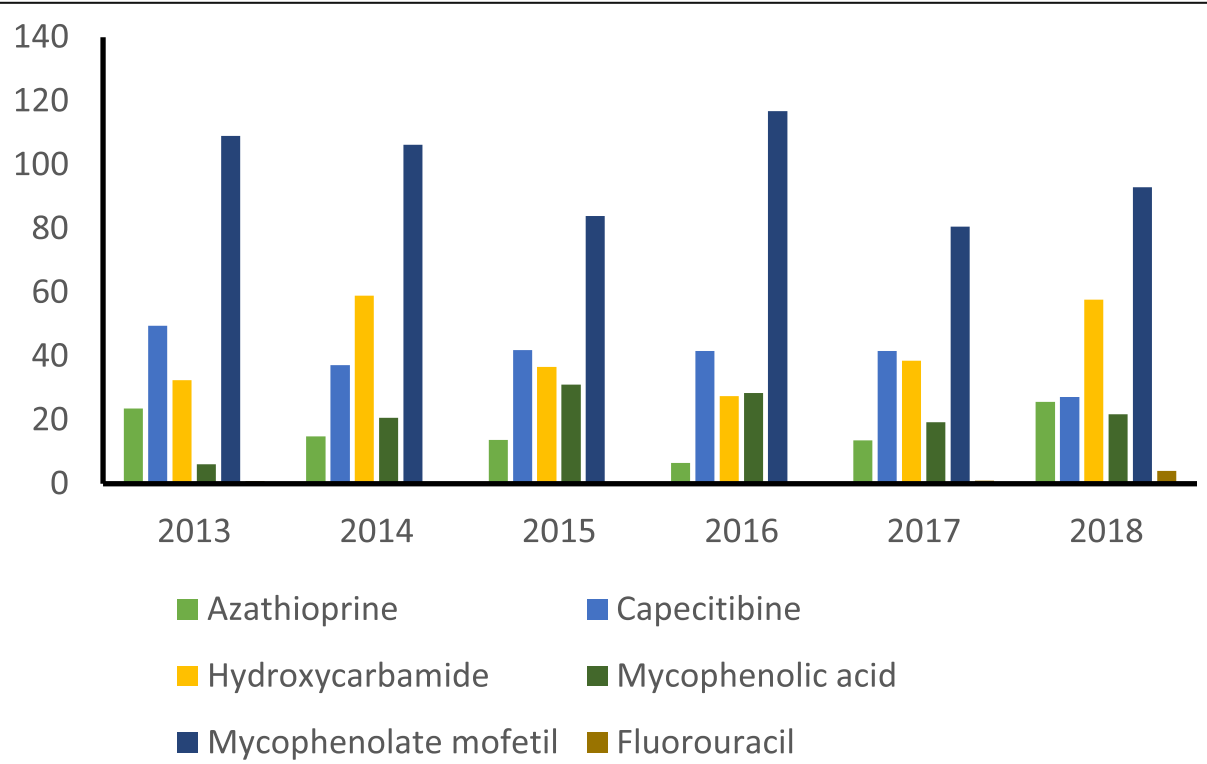

Fig. 5 PEC value of the 6 priority chemotherapeutic drugs in Lebanon 
DNA damage and massive whole-transcriptome changes [33]. Another study by Misik et al. reports an increased frequency of abortive grains in higher plants exposed to 5-fluorouracil [34].

In addition, with the geographical location of Lebanon in mind, a need is to emphasize the impact of those micropollutants on neighboring countries that share the Mediterranean Sea, including but not limited to Algeria, Croatia, Cyprus, Egypt, France and Greece.

\section{The need for regulations Importance of WWTPS}

It is indeed essential to pay special attention to the discharge of these drugs in the environment. It is worth noting that not all wastewater treatment techniques are effective at removing anticancer drugs. The scarce literature available shows that a promising method for the removal of micropollutants is the membrane bioreactor which combines physical removal with biological removal (biodegradation) to improve the outcome of the wastewater treatment [6]. Unfortunately, in Lebanon, efficient WWTPs are totally absent. The establishment of such plants is therefore a pressing matter that should be considered as top priority by the Lebanese authorities to protect the public from the danger of such micropollutants.

\section{Pharmaceutical waste management in Lebanon}

In this paper, we have tackled the risks imposed by a major source of chemotherapeutic drug in surface waters: the chemotherapeutic drugs consumed by the patients in medical centers as well as their home. However, another major source of micropollutants are expired/unused drugs that stay at the importer's warehouses and do not reach hospitals/patients. In the absence of a safe solution and the necessary regulations to dispose of pharmaceutical surplus, warehouses in Lebanon are filling up with old, expired drugs [35]. Efforts are needed to set new policies regarding the disposal of micropollutants in general, and chemotherapeutic drugs primarily.

\section{Future studies needed}

Our research study is the first of its kind in Lebanon and the Middle East. As previously stated, in this study, we have estimated the environmental concentrations in surface waters by the calculation of PECs based on consumption data. Reports on the occurrence of chemotherapeutic drugs in surface water, ground water or drinking water by measurement of actual drug concentrations are absent. The purpose of our study is to shed light on the risks that these drugs impose and pave the way for future studies that tackle measurement of the actual concentrations of these micropollutants in Lebanese waters.

\section{Conclusions}

Globally, there is a growing attention regarding the fate of pharmaceuticals in the environment and their potential toxicity to different species. All pharmaceuticals, by design, are meant to elicit a biological response. Chemotherapeutic drugs are of a particular concern. The analysis showed that the top five most commonly consumed drugs are: MMF, hydroxycarbamide, capecitabine, MPA and azathioprine. A preliminary analysis of the toxicity risk based on the assessment of exposure allowed the identification of six potentially priority drugs, belonging to classes IA (high-risk compounds) and IIA (potentially hazardous compounds): MMF, hydroxycarbamide, capecitabine, MPA, azathioprine and 5-fluorouracil. Our analysis has also proven that, when analyzing the potential risk of such micropollutants, it is a key pre-requisite to combine drugs with common end product, as their toxicity cannot be separated. Further analysis of these priority micropollutants is necessary, with actual measurement, rather than estimation, of their occurrence in surface waters. In this study, we have shed light on potential contaminants of our surface waters, emphasizing the importance of efficacious WWTPs and the enforcement of regulations with regard to environmental pollution.

\section{Acknowledgements \\ The authors thank the Lebanese American University for financing this research project.}

\section{Authors' contributions \\ Y. Saab was responsible for the conceptualization and design of the study, acquisition of the data and critical data analysis and revision of the manuscript. Z. Nakad developed the software needed for the calculations and processed the data. R. Rahme worked on the computation and interpretation of data and drafted the article. All authors read and approved the final manuscript.}

\section{Funding}

This research paper was funded by the Lebanese American University.

\section{Availability of data and materials}

All data generated or analyzed during this study are included within the article except for the raw data provided by the MOPH, which will be provided upon request.

\section{Declarations}

\section{Competing interests}

The authors declare they have no competing interests.

\section{Author details}

${ }^{1}$ Department of Pharmaceutical Sciences, School of Pharmacy, Lebanese American University, Byblos 36-F19, Lebanon. ²Department of Computer Engineering, School of Engineering, Lebanese American University, Byblos 36-F19, Lebanon.

Received: 25 October 2020 Accepted: 16 September 2021 Published online: 09 October 2021

\section{References}

1. WHO. 2021 Report on Cancer. Geneva: World Health Organization; 2021 https://www.who.int/news-room/fact-sheets/detail/cancer.

2. WHO. Cancer Country Profile: Lebanon. Geneva: World Health Organization; 2020. https://www.who.int/cancer/country-profiles/LBN_2020.pdf. 
3. Gordon M. Cancer Chemotherapy: Drug Classification and Mechanism of Action. Medical Pharmacology Education Website; 2000. https://www.pha rmacology2000.com/Chemotherapy/Anticancer/classes1.htm.

4. Balcerzak W, Rezka P. Occurrence of anti-cancer drugs in the aquatic environment and efficiency of their removal - the selected issues. Tech Trans Environ Eng. 2014;1:11-8.

5. Jureczko M, Kalka J. Cytostatic pharmaceuticals as water contaminants. Eur J Pharmacol. 2020;866:172816.

6. Climent LF. Analysis of chemotherapy drugs and related compounds in aquatic environment: removal, transformation and risk evaluation in ecofriendly and advanced technologies [Ph.D. Dissertation]. Girona: University of Girona; 2016.

7. Tambosi JL, Yamanaka LY, Jose HJ, Moreira RDPM, Schroder HF. Recent research data on the removal of pharmaceuticals from sewage treatment plants (STP). Quim Nova. 2010;33:411-20.

8. PDR. Myfortic Drug Information. Whippany: Prescriber's Digital Reference; 2020. https://www.pdr.net/drug-information/myfortic?druglabelid=435.

9. Straub JO. Combined environmental risk assessment for 5-fluorouracil and capecitabine in Europe. Integr Environ Assess Manag. 2010;6:540-66.

10. Green DM, Nolan VG, Goodman PJ, Whitton JA, Srivastava D, Leisenring WM, et al. The cyclophosphamide equivalent dose as an approach for quantifying alkylating agent exposure: a report from the Childhood Cancer Survivor Study. Pediatr Blood Cancer. 2014;61:53-67.

11. Shankar SM, Marina N, Hudson MM, Hodgson DC, Adams MJ, Landier W, et al. Monitoring for cardiovascular disease in survivors of childhood cancer: report from the cardiovascular disease task force of the children's oncology group. Pediatrics. 2008;121:E387-96.

12. Izbicka E, Diaz A, Streeper R, Wick M, Campos D, Steffen R, et al. Distinct mechanistic activity profile of pralatrexate in comparison to other antifolates in in vitro and in vivo models of human cancers. Cancer Chemoth Pharm. 2009;64:993-9.

13. Fujii Y, Yonese J, Kawakami S, Yamamoto S, Okubo Y, Fukui I. Equivalent and sufficient effects of leuprolide acetate and goserelin acetate to suppress serum testosterone levels in patients with prostate cancer. BJU Int. 2008;101: 1096-100.

14. Santos MSF, Franquet-Griell H, Lacorte S, Madeira LM, Alves A. Anticancer drugs in Portuguese surface waters - estimation of concentrations and identification of potentially priority drugs. Chemosphere. 2017;184:1250-60.

15. FDA. Environmental Assessment of Human Drug and Biologics Applications. Silver Spring: Food and Drug Administration; 1998.

16. EMA. Environmental Risk Assessment of Medicinal Products for Human Use. Amsterdam: European Medicines Agency; 2006.

17. WM. Lebanon Demographics. Worldometer; 2020. https://www. worldometers.info/demographics/lebanon-demographics/.

18. NLM. PubChem. Bethesda: National Library of Medicine; 2021.

19. Giebultowicz J, Nalecz-Jawecki G. Occurrence of immunosuppressive drugs and their metabolites in the sewage-impacted Vistula and Utrata Rivers and in tap water from the Warsaw region (Poland). Chemosphere. 2016:148:137-47.

20. Franquet-Griell H, Gomez-Canela C, Ventura F, Lacorte S. Predicting concentrations of cytostatic drugs in sewage effluents and surface waters of Catalonia (NE Spain). Environ Res. 2015;138:161-72.

21. MW. Global Hydroxycarbamide Market Report 2021, Major Region, Market Value, cagr, Market Competition, Latest Demands, Main Consumer, Regional Production, Impact Due to Covid-19 and Forecast by 2021-2025. Market Watch; 2021.

22. Johnson AC, Jurgens MD, Williams RJ, Kummerer K, Kortenkamp A, Sumpter JP. Do cytotoxic chemotherapy drugs discharged into rivers pose a risk to the environment and human health? An overview and UK case study. J Hydrol. 2008;348:167-75

23. Besse JP, Garric J. Human pharmaceuticals in surface waters. Implementation of a prioritization methodology and application to the French situation. Toxicol Lett. 2008;176:104-23.

24. Kosjek T, Perko S, Zigon D, Heath E. Fluorouracil in the environment: analysis, occurrence, degradation and transformation. J Chromatogr A. 2013; 1290:62-72.

25. Chaaya M, Slim ZN, Habib RR, Arayssi T, Dana R, Hamdan O, et al. High burden of rheumatic diseases in Lebanon: a COPCORD study. Int J Rheum Dis. 2012;15:136-43.

26. Misik M, Filipic M, Nersesyan A, Kundi M, Isidori M, Knasmueller S. Environmental risk assessment of widely used anticancer drugs (5- fluorouracil, cisplatin, etoposide, imatinib mesylate). Water Res. 2019;164: 114953.

27. Kummerer $\mathrm{K}, \mathrm{Al}$-Ahmad A. Estimation of the cancer risk to humans resulting from the presence of cyclophosphamide and ifosfamide in surface water. Environ Sci Pollut R. 2010;17:486-96.

28. Roche. Environmental Risk Assessment Summary: Erlotinib. Basel: Roche; 2020

29. Kundi M, Parrella A, Lavorgna M, Criscuolo E, Russo C, Isidori M. Prediction and assessment of ecogenotoxicity of antineoplastic drugs in binary mixtures. Environ Sci Pollut R. 2016;23:14771-9.

30. Heath $E_{1}$ Filipic $M$, Kosjek T, Isidori M. Fate and effects of the residues of anticancer drugs in the environment. Environ Sci Pollut R. 2016;23:14687-91.

31. Misik M, Filipic M, Nersesyan A, Misikova K, Knasmueller S, Kundi M. Analyses of combined effects of cytostatic drugs on micronucleus formation in the Tradescantia. Environ Sci Pollut R. 2016:23:14762-70.

32. Straub JO, Oldenkamp R, Pfister T, Haener A. Environmental risk assessment for the active pharmaceutical ingredient mycophenolic acid in European surface waters. Environ Toxicol Chem. 2019;38:2259-78.

33. Kovacs R, Csenki Z, Bakos K, Urbanyi B, Horvath A, Garaj-Vrhovac V, et al. Assessment of toxicity and genotoxicity of low doses of 5-fluorouracil in zebrafish (Danio rerio) two-generation study. Water Res. 2015;77:201-12.

34. Misik M, Kundi M, Pichler C, Filipic M, Rainer B, Misikova K, et al. Impact of common cytostatic drugs on pollen fertility in higher plants. Environ Sci Pollut R. 2016;23:14730-8.

35. TDS. Expired pharmaceuticals dumped in warehouses. Beirut: The Daily Star; 2017.

\section{Publisher's Note}

Springer Nature remains neutral with regard to jurisdictional claims in published maps and institutional affiliations.

Ready to submit your research? Choose BMC and benefit from:

- fast, convenient online submission

- thorough peer review by experienced researchers in your field

- rapid publication on acceptance

- support for research data, including large and complex data types

- gold Open Access which fosters wider collaboration and increased citations

- maximum visibility for your research: over $100 \mathrm{M}$ website views per year

At $\mathrm{BMC}$, research is always in progress.

Learn more biomedcentral.com/submissions 